\title{
Energy Poverty: Practical and Structural Solutions for South-East Europe
}

\author{
Lidija Živčič ${ }^{1, *}$, Tomislav Tkalec ${ }^{1}$, Slavica Robić ${ }^{2}$ \\ ${ }^{1}$ Association for Sustainable Development, Slovenia \\ ${ }^{2}$ Society for Sustainable Development Design, Croatia
}

Copyright $(\mathrm{C} 2016$ by authors, all rights reserved. Authors agree that this article remains permanently open access under the terms of the Creative Commons Attribution License 4.0 International License

\begin{abstract}
Energy poverty poses serious issue in the South- East Europe (SEE). It is estimated that about $30 \%$ of households in SEE are struggling with adverse effects of energy poverty. This article presents findings of a research undertaken in four SEE countries, namely Bulgaria, Croatia, Macedonia and Slovenia, where the project "Reduce Energy Use and Change Habits" (REACH) is implemented. The aim of the project REACH is to contribute to energy poverty abatement at both practical and structural level. Activities undertook within project REACH focus on rationalising the use of energy and water in energy poor households. Households have been provided with tailor-made energy advices, empowering them to change their energy and water use habits. Students and teachers from vocational schools have been educated as energy advisors, enabling them to perform visits to the selected households and implement energy efficiency measures. By implementing activities under the project REACH it has proven to be likely that through provision of energy advising and implementation of simple energy efficiency measures, households' energy consumption can be reduced up to $10 \%$ and water consumption up to $18 \%$. Results are also indicating that policies focusing on energy efficiency measures are likely to be the best mechanism for alleviating energy poverty. This is especially the case when energy and social policies are harmonised with the aim of alleviating adverse effects of energy poverty.
\end{abstract}

Keywords Energy Efficiency, Energy Poverty, Energy and Water Saving Measures, Energy Poor Households

\section{Introduction}

Project REACH is an on-going project and not all the outcomes and results can be fully documented and presented in this article. However, as project REACH is closely related to already implemented project ACHIEVE and its tested methodology, the research presented in this paper delivers proven methodology and tested results. Findings from ACHIEVE have been successfully replicated in REACH thus adding different angles to the presented methodology.

The methodology builds on experience gained through successfully implemented projects ACHIEVE and EC LINC $^{1}$. As it was built upon previously tested methodology, modified based on lessons learned, results arising from activities implemented within project REACH are very similar to the results of ACHIEVE. Thus, results of both projects are presented hereafter jointly.

First section of the paper, 1. Introduction, focuses on the context of energy poverty and specifics of the region where research has been undertaken. In the section 2. Objectives, the project $\mathrm{REACH}$ is presented in greater details describing activities, expected results, target groups and relevant local actors. It is followed by the section 3. Methods where approaches, which have been used are presented giving insight into the methodology. Section 4. Results presents practical results of the project so far and results from previous twin project ACHIEVE. It also includes policy recommendations. Section 5. Discussion highlights remaining aspects of the energy poverty, which have not been addressed in the previous sections. Paper is finalises by the section 6. Conclusion, which focuses on key findings and further lessons, that can be drawn from the experience of projects REACH and ACHIEVE. This paper tries to summarize contribution of the project REACH and its methodology as a measure for tackling energy poverty issue on practical and structural level offers suggestions for future actions, with special focus on South-East Europe.

\subsection{Context of the REACH Project}

Even though the European Union is one of the most developed parts of the world, many EU citizens face difficulties in covering their basic energy needs. Between 50 million and 125 million people (about $10-25 \%$ of citizens) in EU are estimated to be 'energy poor' [1]. The variation of energy poverty estimations is so significant mostly because there is no universal definition of energy poverty and as a result, there is no statistic available which would be comparable across countries [2]. However, most of the

1 More information about ACHIEVE and EC LINC is available at http://achieve-project.eu/ and http://www.ec-linc.info/ respectively. 
evidence shows that energy poverty is very likely to worsen in the future, following the increase of energy prices [2]. Adverse effects of energy poverty are particularly evident in Eastern European countries, where the recent liberalization of energy sector, part of their EU accession process, has led many households to energy poverty. Shift from subsidized energy prices into a situation with market based energy prices resulted in significant rise in energy bills [2]. Energy market liberalisation and other geographical and historical specificities of the region make energy poverty situation especially severe in the South-Eastern European (SEE) countries [2,3]. It is estimated that in SEE countries $30 \%$, or more, of households, are struggling with energy poverty [4].

EU is working to address energy poverty, but some important elements are still missing [5]. A crucial step for tackling the energy poverty is to agree on definition, however, there are still many on-going debates on what constitutes energy poverty and how it can be measured [2]. It is important to evaluate and monitor the energy poverty problem [6]. Monitoring and evaluation include collection and analysis of data about energy consumption together with reliable social-economic indicators, in order to properly understand the scope and depth of the problem. Monitoring is still largely missing in the SEE countries.

Despite more than 30 years of efforts, there is no agreement on universal or EU wide definition on energy poverty. During that period, many working definitions have been proposed. First measurable definition was done by Boardman in 1991 [7] stating that energy (fuel) poverty occurs when a households is unable to have adequate energy services for 10 per cent of income. This applies to heating, hot water, lighting and all other energy services within the home, not just warmth. The definition also takes into account following factors $[2,7]$ :

- Temperature: $21^{\circ} \mathrm{C}$ in the living room, $18^{\circ} \mathrm{C}$ elsewhere (WHO)

- Heating: 9 hours a day for those at work or in full time education; 16 hours for those likely to be at home all day

- All rooms, unless under-occupied

- Energy for all services: hot water, lighting, cooking, and all other uses of energy in the home.

UK has used Boardman's definition until Energy Act from 2013 when ground for new legal framework has been laid out using Low Income High Costs indicator (LIHC) as proposed by Hills [8]. Under the LIHC definition, a household is considered to be energy poor if they have required fuel costs that are above average (the national median level) and were they to spend that amount, they would be left with a residual income below the official poverty line. Compared to the previous UK indicator (the need to spend more than $10 \%$ of income), the LIHC compares national median bill and income taking into consideration number of households that have both low incomes and high energy costs and the depth of energy poverty among these households [9].

Schuessler [10] examines groups of indicators, which have up to date been linked to energy poverty and discussed in prior empirical research across Europe, and argues that all these indicators should play a role in the assessment of energy poverty:

- Subjective qualitative assessments by affected persons (e.g., "I cannot afford to heat my rooms adequately");

- Subjective qualitative assessments by others (e.g., social workers);

- Objective non-expenditure-based indicators (e.g., humidity, incidence of mould in housing, epidemiological data);

- Expenditure-based indicators (e.g., income share of energy expenditure).

Bouzarovski [11] argues that energy poverty is a situation where a household is unable to access a materially and socially-necessitated level of energy services in the home. Bouzarovski has been one of the pioneers of research in the field of energy poverty focusing on specificities of SEE. When discussing possible definitions of energy poverty in the SEE context it is important to understand impact of households' physical and institutional settings-in particular the inheritance of an inefficient residential stock built at a time of heavily subsidized energy prices and, very often, connected to an out dated energy supply system [3].

Defining energy poverty has and still is causing numerous debates [12-15], but as this is not the topic of this paper, the issue is addressed only briefly. Boardman [2] explains the challenge in the following manner: All of these definitional issues are compounded by the circular argument: who is energy poor depends on the definition, but the definition depends on who you want to focus on and this involves political judgement. Similarly, Moore [16] implicates that definition of energy poverty is important for policy formulation and measures, which tackle this problem. At the EU level, there is no common definition of what constitutes an energy poor household [17]. However, one way of defining it, which is spotted in practice, is that a household, which has twice the median fuel expenditure as a proportion of income, is facing energy poverty [18].

Applying the Boardman 1991 definition [7] (household that would need to spend more than $10 \%$ of its annual income on having adequate energy services is in energy poverty) to Macedonia results in almost the entire population to be energy poor [19]. A similar situation exists in Croatia [20-21], hence one could assess that the Boardman 1991 definition is not suitable for application in the SEE region.

For the purpose of the projects ACHIEVE and $\mathrm{REACH}^{2}$, the following definition of an energy poor household emerged: energy poor household is one that has a difficulty, or sometimes inability, to be able to afford its basic energy needs [22]. Basic energy needs considered by this represent

2 ACHIEVE and REACH are EU wide projects supported by the Intelligent Energy Europe Programme of the European Union, for addressing energy poverty at practical and structural level. Project ACHIEVE was implemented between 2011 and 2014 in 5 countries: Bulgaria, France, Germany, Slovenia and United Kingdom. Project REACH started in 2014, it is implemented in Bulgaria, Croatia, Macedonia and Slovenia. It will finish in 2017. 
the ability to have adequate energy indoors services: heating, cooling, cooking, lighting. It means being able to keep home adequately warm (as recommended by WHO), to have access to energy efficient refrigerators, freezers, washing machines, to have efficient provision of domestic hot water and indoor lighting.

Energy poverty is mainly caused by the convergence of the following inter-related factors $[1,12]$ :

1. low income, which is often linked to general poverty,

2. high energy prices, including the use of relatively expensive fuel sources,

3. poor energy efficiency (EE) of a home and of used appliances, e.g. through low levels of insulation and old or inefficient heating systems.

Heating is the major part of the energy bill for a household (it represents around $70 \%$ of the annual energy consumption) [23]. Usage of electrical appliances and the energy used for domestic hot water also significantly contribute to increased energy use: appliances account for a growing proportion of households' energy budgets (low income households tend to use older and more inefficient appliances), and water consumption is showing a general tendency to increase (amongst all categories of households) [22].

Energy poverty mostly affects low-income households retired people, unemployed or poorly paid, dependent on social benefits and single parent households [24]. Their economic disadvantage is often matched with poor energy efficiency of their homes, poor insulation, out-dated heating systems, and linked to poor health. It is often the case that energy poor households are socially isolated and lack support from others. In general living conditions of energy poor subject them to physical and mental health risks, and are often leading to total degradation of dwellings and excessive debt. The main needs of those households are adequate energy services and ability to pay energy bills [24]. Project REACH [25] responds to their needs by showing them how to reduce their consumption of energy, providing them with basic energy efficiency measures, teaching them to understand their energy and water bills and assisting them to find support of suitable services, when needed.

\subsection{Specifics of Energy Poverty in the Region, Local Circumstances}

It is commonly falsely assumed that energy poverty has the same characteristic, regardless of the cultural, climatic or political background ${ }^{3}$. Through practice it was shown that regional and historical differences play a significant role in prevalence and characteristics of energy poverty.

The SEE region has some specific characteristics as compared to other parts of the EU. Energy poverty is still an issue of low or no political interest in the region, and hence the problem is less defined, monitored or tackled than in Western European countries like UK or France. In SEE

3 Unless specified otherwise, the content of this sections 1.2 Specific of energy poverty in the region, local circumstances, 2 . Objectives and 3 . Methods comes from the REACH project documentation [25]. countries, no clear division between social housing and non-social housing buildings or areas can be detected. Citizens of SEE countries had to make a switch from subsidized energy prices to market based prices which resulted in continuous and significant increase in consumer prices. Furthermore, in SEE countries there is almost no existing social support for energy poor households as in the rest of EU.

This different context was taken into consideration when implementing project REACH. In SEE countries, most of the households can benefit from installation of 'low-tech' devices, such as draft proofing of windows or efficient light bulbs, while this was not the case for Germany or the UK (e.g. in Germany or UK double glazing is a standard).

Project REACH is implemented in 4 SEE countries, where 5 pilot regions were selected ( 2 in Slovenia and 1 in Bulgaria, Croatia and Macedonia). Following paragraphs present current situation in targeted countries and regions.

Bulgaria, Plovdiv area: Recent events in Bulgaria demonstrated that a large part of the population is facing difficulties when paying their energy bills. Also statistics show that the problem with energy poverty is severe in Bulgaria: if the UK definition of energy poverty is applied in Bulgaria, then more than $75 \%$ of Bulgarian households should be regarded as energy poor. This means that the problem must be tackled with structural approach at national level. The Bulgarian Energy Efficiency Act, National Programme for Retrofitting of Homes and the Winter Supplement Programme are important national initiatives that the proposed project can build on. In Plovdiv area each year more than 9000 households apply for social funding to be able to afford their energy bills in the winter. More than $20 \%$ of them are rejected, while many households cannot apply for funding because of administrative criteria.

Croatia, Sisak-Moslavina County (SMC): Although Croatia lacks official statistics related to energy poverty, most vulnerable areas can easily be identified and related to high energy poverty risk factor considering statistical data on average income and average fuel/energy costs. The SMC is facing some key development issues, such as unequal population distribution and unequal development rate between different parts of the County. There is continuous process of ageing of population. In the SMC there is also a high unemployment rate of $27.4 \%$ with continuous growth, compared to the state average of $15 \%$. The average personal income in SMC in 2011 was 5041 HRK (approx. 670 EUR) with significant portion of income being spent on energy and housing costs. Considering the high poverty prevalence, ageing of population and low employment rate this area is likely to be highly affected by energy poverty.

Macedonia, Skopje area: There are no official statistics on energy poverty in Macedonia, so it is hard to estimate the scope of the problem. However, 20.000 households (4\%) have used the governmental subsidy to reduce energy poverty, which gives an indication that the problem is not marginal. The energy consumption (electricity usage) in the target area is high due to inefficient and old domestic 
appliances and insufficient knowledge about efficient use of energy. The target group includes households with low incomes, who are unable to pay the energy bills. The targeted area includes low income households that are predominantly situated in the rural areas. Nonetheless, there are lots of them that are randomly situated in the city. These households are not capable to cover their general expenses, including the energy bills (electricity, district heating, and firewood), which results in inadequate living conditions. The EVN Macedonia, which is national electricity distributing company, already has some activities that include education of low income households about proper energy usage. They also included the bill reducing program for these households in order to improve their financial capabilities. On the other hand, the Public Enterprise "Makedonski Sumi" through the common project of the Government of Republic of Macedonia and the Ministry of Agriculture, Forestry and Water Economy approved decrease of the prices of firewood for $30 \%$ in the previous year to intercept the needs of all households that are using this kind of energy.

Slovenia, Zasavje and Pomurje regions: Assessment of Institute of Macroeconomic Analysis and Development shows that in Slovenia almost one third of the households live in energy poverty according to the UK definition. In addition to problems with paying the bills this also means a lower quality of life due to unhealthy housing conditions. At the moment there are several government programs for tackling energy poverty, one of them being a national program for visiting energy poor households. Project REACH, however, focuses on the regions of Zasavje and Pomurje because of their exposure to the risk of energy poverty: the least developed regions in Slovenia with the most acute social and economic problems. They have the highest rates of unemployment (Pomurje 19,3\%, Zasavje $16,5 \%$ in comparison to national average of $13,6 \%$ ) and the lowest average wages in Slovenia. Zasavje region is facing another problem: it used to be a mining region, but as the mining is phasing out, employment opportunities are lacking.

\section{Objectives}

Project REACH is funded by the Intelligent Energy Europe programme and designed to offer practical and structural solutions that help to mitigate energy poverty. The project focuses on most vulnerable households, empowering them to reduce their consumption of energy and water and strives to establish energy poverty as a policy issue.

\subsection{Aim and Objectives of REACH}

The aim of REACH is to contribute to energy poverty abatement at practical and structural level. This aim translates into twofold overall objective of the action, which is to empower energy poor households (vulnerable consumers) to take actions to save energy and change their habits, and to establish energy poverty as an issue that demands structural solutions (tailor-made policies and measures) at local, national and EU level.

The overall objective of the action is supported by specific and strategic objectives. Specific objectives include a) compilation of data and analysis of energy poverty situations in 4 selected countries, in order to form definition(s) of energy poverty and policy recommendations; b) engagement and empowering of local actors to tackle energy poverty in 5 pilot areas; c) empowering of 1600 households to reduce their energy and water use, hence reducing their energy use by averagely $10 \%$ and cutting their $\mathrm{CO}_{2}$ emissions by 200 $\mathrm{kg} /$ year on average; d) engaging 160 decision-makers in tackling energy poverty as an issue that demands structural tailor-made solutions and create a platform for concerted formulation of structural solutions at national and EU level.

The strategic objectives of the action include a) identification of available approaches for energy poverty abatement that are applicable to other regions in order to launch similar actions; b) sustainability of local actions in the pilot regions and spreading it to other interested localities and countries; c) engagement of energy poor households in continuous efforts to save energy by showing them that change of habits in combination with small initial investments can help them get out of energy poverty and d) ensuring that energy poverty receives structural response in local, national or EU policies that will include tailor-made measures for energy poverty challenges.

\subsection{REACH Activities, Expected Results and Impacts}

REACH builds on several key steps - activities. Firstly, the implementing partners have been well familiarised with energy poverty challenges and solutions in various EU countries gaining detailed insight into the field of energy poverty. The next step was analysing the situation in the field of energy poverty on the national level followed by the local level analyses for selected pilot areas. These analyses formed the basis for policy work. The next important aspect of all undertaken activities is transferring knowledge, know-how and skills from experienced partners to partners with less or no experience and further to teachers and students (energy advisors), who have performed energy advising in energy poor households. The practical part of the project connects activities that are needed to visit energy poor households and empower them to reduce their energy and water use. In line with the developed local action plans and the training of energy advisors, this line of activity brings free energy audits and tailor-made advice to energy poor households. Starting step is shaping and implementing the local promotion campaigns for households. This is followed by organisation and implementation of visits in two stages: the first visit to perform energy audit and the second visit to deliver tailor-made package of devices and advice to save energy and water. Post-visit support is also available to the households. Next package of activities tries to establish energy poverty as a policy issue that needs structural tailor-made solutions. It brings a set of activities to endorse energy poverty among decision-makers and trigger their response and action. Policy recommendations, both for 
national and EU level, are provided and a mix of activities is implemented to place energy poverty on the national and EU policy agenda. An important activity is the evaluation of the activities. This set of activities evaluates action's impacts to understand the effectiveness of the activities and achievements that the action brought. The evaluation of the household visits and the evaluation of the policy work are both part of the project.

Table 1 presents the expected results and impacts of the action. Table 2 present the strategic objectives of the action and expected impacts by 2020 . Table 3 presents the expected contributions of REACH project to the EU 2020 targets on energy efficiency and renewable energy sources.

Table 1. Expected results and impacts of project REACH

\begin{tabular}{|c|c|c|}
\hline $\begin{array}{l}\text { Specific Objectives of } \\
\text { the action }\end{array}$ & $\begin{array}{c}\text { Key outputs (products and services) including their } \\
\text { quantification where appropriate }\end{array}$ & $\begin{array}{l}\text { Impacts, with SMART performance indicators and } \\
\text { quantified targets }\end{array}$ \\
\hline $\begin{array}{l}\text { Compile data and } \\
\text { analyse energy poverty } \\
\text { situation in } 4 \text { countries }\end{array}$ & $\begin{array}{l}\text { - implemented } 1 \text { day workshop for sharing EU } \\
\text { know-how with 5-6 experts } \\
\text { established overview of energy poverty for } 4 \\
\text { countries (10-12 pages) in English and national } \\
\text { languages }\end{array}$ & $\begin{array}{l}\text { at least } 15 \text { representatives of partners and other } \\
\text { interested organisations aware of up-to-date } \\
\text { achievements in energy poverty field } \\
\text { established basis for shaping policy recommendations } \\
\text { and organising national and EU level policy work }\end{array}$ \\
\hline $\begin{array}{l}\text { Engage and empower } \\
\text { local actors to tackle } \\
\text { energy poverty in } 5 \\
\text { pilot areas ( } 5 \text { informed } \\
\text { and engaged local } \\
\text { actors, } 4 \text { trained } \\
\text { teachers and } 50 \text { trained } \\
\text { energy advisors in each } \\
\text { pilot area) }\end{array}$ & 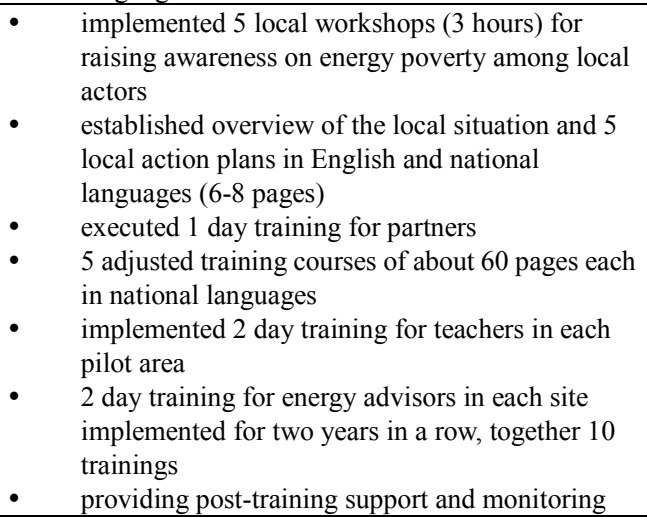 & $\begin{array}{l}\text { - at least } 10 \text { local actors familiar with energy poverty in } \\
\text { each pilot area, together } 50 \text { actors } \\
\text { at least } 5 \text { local actors involved in assessment of local } \\
\text { situation in each pilot area } \\
\text { networks established between at least } 5 \text { local actors in } \\
\text { each pilot area } \\
\text { at least } 8 \text { trained partners ( } 2 \text { per country) and at least } 6 \\
\text { trained other persons, together at least } 14 \text { persons } \\
\text { trained to train energy advisers } \\
\text { at least } 4 \text { teachers (or other relevant multipliers) } \\
\text { trained per pilot site, together } 20 \text { trained teachers } \\
\text { at least } 25 \text { participants in each energy advisor training, } \\
\text { together } 250 \text { energy advisors trained } \\
\text { at least } 30 \text { assisted visits per site, together at least } 150 \\
\text { assisted visits }\end{array}$ \\
\hline $\begin{array}{l}\text { Empower } 1600 \\
\text { households to reduce } \\
\text { their energy and water } \\
\text { use and provide at least } \\
400 \text { of them with } \\
\text { further support for } \\
\text { tackling their } \\
\text { problems, hence } \\
\text { reducing their energy } \\
\text { use by averagely } 10 \% \\
\text { and cutting their } \mathrm{CO}_{2} \\
\text { emissions by } \\
200 \mathrm{~kg} / \text { year on average }\end{array}$ & 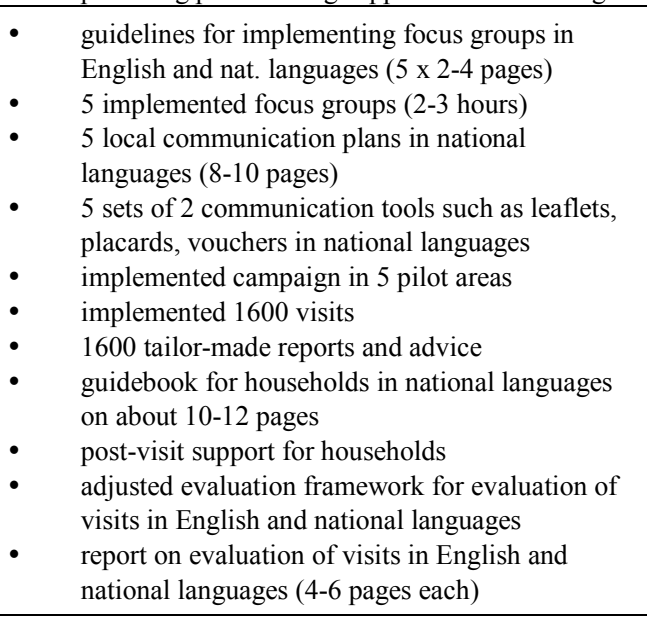 & 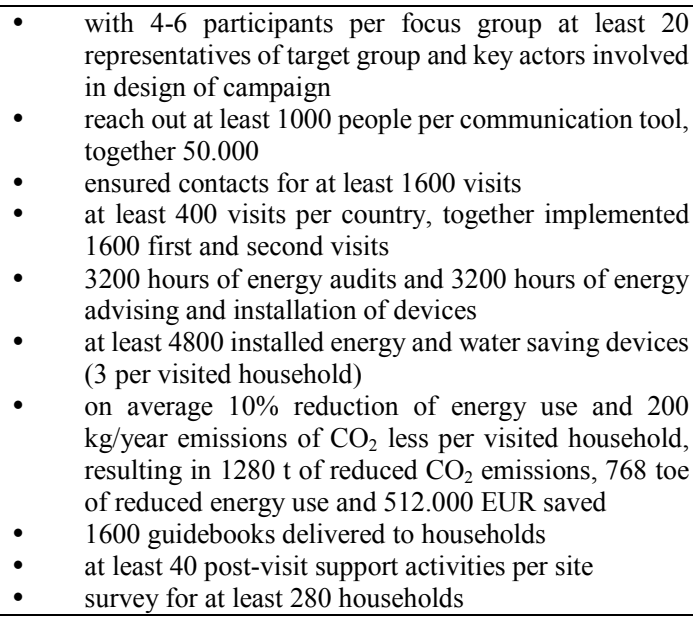 \\
\hline $\begin{array}{l}\text { Engage } 120 \\
\text { decision-makers at } \\
\text { national and } 40 \text { at EU } \\
\text { level in tackling energy } \\
\text { poverty as an issue that } \\
\text { demands structural } \\
\text { tailor-made solutions, } \\
\text { provide them with } \\
\text { recommendations on } \\
\text { how to address the } \\
\text { problem and create a } \\
\text { platform for concerted } \\
\text { formulation of } \\
\text { structural solutions at } \\
\text { national and EU level }\end{array}$ & 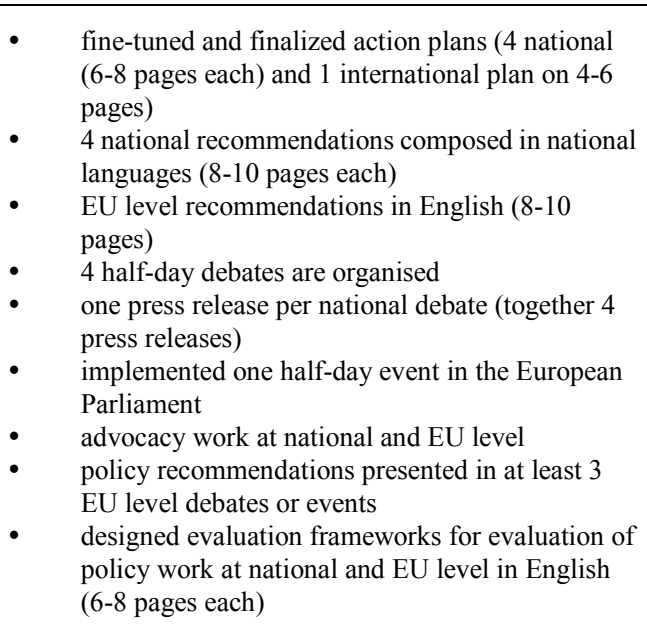 & 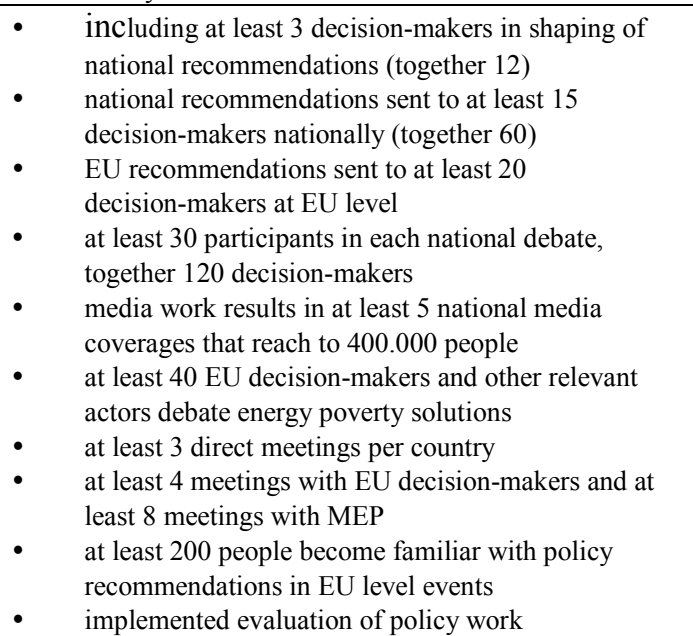 \\
\hline
\end{tabular}


Table 2. Strategic objectives of the action and expected impacts by 2020

\begin{tabular}{|c|c|}
\hline Strategic objectives of the action & Expected impacts by 2020 \\
\hline $\begin{array}{l}\text { To make available approaches for energy poverty abatement that are } \\
\text { applicable to SEE and CEE regions in order to launch similar action } \\
\text { elsewhere in the region }\end{array}$ & At least three new countries pick up the approach from REACH \\
\hline $\begin{array}{l}\text { To sustain local actions in the pilot regions on a long run and spread it to } \\
\text { other interested localities and countries by continued training of energy } \\
\text { advisors in schools, continued implementation of visits, and promoting } \\
\text { the action to variety of actors across EU }\end{array}$ & $\begin{array}{l}\text { Five generations of energy advisors trained in each pilot site ( } 225 \mathrm{new} \\
\text { advisors), at least } 50 \text { visits per site per year are implemented by local } \\
\text { actors (additional } 1250 \text { visits, contributing to further savings of } 600 \text { toe, } \\
\qquad 1 \text { million } \mathrm{tCO}_{2} \text { and } 400.000 \text { EUR) }\end{array}$ \\
\hline $\begin{array}{l}\text { To engage energy poor households in continuous efforts to save energy } \\
\text { and reduce environmental impacts by showing them that change of habits } \\
\text { in combination with small initial investments can help them get out of } \\
\text { energy poverty }\end{array}$ & $\begin{array}{l}1600 \text { households make further } 10 \% \text { reduction in energy use plus a new } \\
\text { cycle of investment, similar to one delivered free in REACH, resulting } \\
\text { in } 48.000 \text { EUR new investments and saving } 768 \text { toe of energy, } 1280 \mathrm{t} \text { of } \\
\qquad \mathrm{CO}_{2} \text { and } 510.000 \text { EUR) }\end{array}$ \\
\hline $\begin{array}{l}\text { To ensure that energy poverty receives structural response in local, } \\
\text { national or EU policies and measures by including tailor-made measures } \\
\text { for energy poverty challenges in variety of policies and action plans }\end{array}$ & $\begin{array}{l}\text { Policies and measures target } 10 \% \text { of energy poor households in Europe } \\
\text { by actions, similar to REACH, through systematic approach, resulting } \\
\text { in saving } 900.000 \text { toe, } 1.2 \text { million } \mathrm{t}_{2} \text { and } 480 \text { million EUR }\end{array}$ \\
\hline
\end{tabular}

Overall aim of the project REACH is to achieve measureable results - reducing energy use by $10 \%$, which, taking into consideration current average energy use per household of 1,2 toe per year ${ }^{4}$ brings about 0,12 toe reduction per household. The $\mathrm{CO}_{2}$ savings per household are aimed at $200 \mathrm{~kg}$ per year. About 30 EUR worth of investment into energy efficiency brings about 80-90 EUR savings per year. The post action period covers 2017-2020, hence 4 years are considered as delivery period, except in case of policies and measures, where only 3 years are considered as delivery period due to delay in applying the measures. The number of energy poor households, covered by policies and measures, is calculated on the basis that EU has about 200 million households across its 27 Member States - if $10 \%$ of those are energy poor (conservative estimation, realistic number is likely to be higher) and $10 \%$ of the energy poor are addressed with measures, similar to REACH, it is $1 \%$ of the 200 million, thus 2 million energy poor households covered by policies and measures.

Table 3. Contributions of REACH to EU 2020 targets

\begin{tabular}{|c|c|c|}
\hline $\begin{array}{c}\text { Overall } \\
\text { objective }\end{array}$ & $\begin{array}{l}\text { Target within the } \\
\text { action duration : }\end{array}$ & Target by 2020: \\
\hline \multirow{3}{*}{$\begin{array}{l}\text { To contribute } \\
\text { to the EU } 2020 \\
\text { targets on } \\
\text { energy } \\
\text { efficiency and } \\
\text { renewable } \\
\text { energy sources }\end{array}$} & $\begin{array}{c}\text { Cumulative investment } \\
\text { made by European } \\
\text { stakeholders in } \\
\text { sustainable energy: } \\
48.000 €\end{array}$ & $\begin{array}{c}\text { Cumulative investment } \\
\text { made by European } \\
\text { stakeholders in } \\
\text { sustainable energy: } 60 \\
\text { million } €\end{array}$ \\
\hline & $\begin{array}{c}\text { Primary energy savings } \\
\text { compared to } \\
\text { projections: } 288 \\
\text { toe/year } \\
\end{array}$ & $\begin{array}{c}\text { Cumulative Primary } \\
\text { energy savings } \\
\text { compared to } \\
\text { projections: } 902.136 \text { toe }\end{array}$ \\
\hline & $\begin{array}{c}\text { Reduction of } \\
\text { greenhouse gas } \\
\text { emissions: } 320 \mathrm{t} \\
\mathrm{CO}_{2} \mathrm{e} / \text { year }\end{array}$ & $\begin{array}{c}\text { Cumulative Reduction } \\
\text { of greenhouse gas } \\
\text { emissions: } 1,2 \text { million } \mathrm{t} \\
\mathrm{CO}_{2} \mathrm{e}\end{array}$ \\
\hline
\end{tabular}

\subsection{REACH Target Groups and Local Actors}

Target groups of project REACH are:

- energy poor households: Energy poverty affects

4 Bulgaria about 0,8 toe, Croatia about 1,2 toe, Slovenia about 1,6 toe. mostly low-income households - retired people, unemployed or poorly paid, dependent on social benefits. The action empowers them to tackle this problem by providing them with free energy audits and advice, as well as with a package of devices to reduce their energy and water use. They will also receive further information to help them change their habits and where needed, and further support. The action aims at empowering 1600 households across the 4 countries, covered by REACH.

- local, national and EU level decision makers: Decision-makers are the politicians and members of public authorities that are able to impact decisions on policies and measures (such as mayors, parliament members or local/national officials working on specific issues). The action deepens their understanding of the energy poverty problem and equips them with a range of possible solutions to address the problem. It also triggers their engagement by providing a platform for concerted formulation of structural solutions. Action expects to engage at least 5 local, 120 national and 40 EU level decision-makers in tackling energy poverty. This target group is also a key actor in the action.

- local actors that can help address energy poverty: This target group is a diverse one, the key common characteristic being that it joins actors that can tackle energy poverty at local level in a systematic manner. It is composed of actors, such as social care/support services, local authorities, social advisors, schools, local energy providers, building managers... The mix of actors will be specific for each pilot region. The action will engage at least 20 local actors in tackling energy poverty challenges locally. This target group is also a key actor in the action.

Key actors of project REACH are:

- vocational schools: Qualifying students to deal with energy systems, energy use or energy using appliances, vocational schools are often unable to provide students with practical experience. Thus they 
are an important actor, which can benefit from the action by providing students with real life experience, while contributing to practical steps to help energy poor households cut down on their energy use. Action will provide training to teachers and students, plus offer them post training support and support in implementing visits in households. Action intends to involve at least 20 teachers and at least 250 students. Engaging students in energy efficiency actions also ensures the sustainability of the proposed measures for energy use reduction in homes as some share of students are likely to implement the measures they were taught about in their own homes,

- local actors that can help address energy poverty: Local energy poverty situations are best addressed by local actors. Hence they will be involved in the action through helping to design actions framework locally and participating in implementation of the action locally.

- local, national and EU level decision makers: Apart from being a target group, they are also a relevant actor in the action. Action will engage them in seeking structural solutions to energy poverty on local, national and EU level.

\section{Methods}

\subsection{Two Levels of Taking Action: Practical and Structural}

For households that are facing difficulties with covering their basic energy bills, immediate action is needed. This is why the practical support represents a key segment of the project REACH. Empowering energy poor households to reduce energy use is an important step in energy poverty abatement. However, it needs to be accompanied by wider measures on policy level. The practical measures can only help to some extent, but cannot significantly change the situation. For example, the practical measures can reduce heating energy use by approximately $10 \%$, but to achieve savings of a larger order, buildings need to be renovated and this is already a step that demands more structured approach and cooperation of several actors. This is why the policy work towards structural measures represents the second core of the action. Details of both levels of work are presented hereafter.

\subsection{Practical Approaches to Abating Energy Poverty}

\section{Mapping of the energy poverty situation}

The first step was to familiarize the partners implementing project REACH with energy poverty challenges and solutions in various EU countries as to help them gain an insight into the field of topic. It was done through a conference on energy poverty, where information, know-how and experience at the EU level were exchanged. Experts, covering various aspects of the energy poverty issues (definition of energy poverty, recognition of energy poverty, communication challenges, practical solutions to energy poverty, structural solutions to energy poverty) helped the partners gain a better insight in achievements up to date.

The next step was mapping of the national and local situation. Data availability for the field of energy poverty is a challenging issue in all countries covered by REACH. Available data on energy poverty has been collected encompassing all relevant categories. Data collected included information on general poverty, unemployment, difficulties to pay bills, energy efficiency class of building as well as of devices used. Collected data was analysed in order to provide insight into the scope and depth of the energy poverty. A joint framework for data collection and analysis was established, defining questions that the country reports needed to answer. Reports provided information about the scope and depth of energy poverty problem in the countries [26-29]. Based on the analysed data the reports also suggest possible definitions of energy poverty in the partner countries and outline possible responses to the problem (on the basis of studies and experience in other countries).

In a similar manner the mapping of the local situation was done. Identifying the right households, accessing channels to reach them and engaging the right actors was an important challenge that the mapping exercise answered ${ }^{5}$. As energy poverty is not a term that many actors understand, the awareness of the local actors needed to be raised first. To this end the partners conducted meetings with the local actors to bring their understanding of the energy poverty problem to the same level.

\section{Transferring experience and know-how}

Project REACH has been implemented in Bulgaria and Slovenia where project partners already participated in ACHIEVE project, and in Croatia and Macedonia where energy poverty has not been systematically tackled prior to REACH. For this reason transferring of practical experience, know-how and skills from experienced partners to partners with less experience was needed. Slovenian and Bulgarian

5 Detailed information on energy poverty in the project's pilot areas can be found in:

- Local action plan on fuel poverty: Plovdiv area, Bulgaria, http://reach-energy.eu/wordpress/wp-content/uploads/2014/12/D2.4EAP EN.pdf, 2014.

- Local action plan on energy poverty: Sisačko-Moslavačka County, Croatia,

http://reach-energy.eu/wordpress/wp-content/uploads/2014/12/D2.4DOOR EN.pdf, 2014.

- Local action plan on energy poverty: City of Skopje arena, Macedonia,

http://reach-energy.eu/wordpress/wp-content/uploads/2014/12/D2.4Macef_EN.pdf, 2014.

- $\quad$ Local action plan on energy poverty: Zasavje, Slovenia, $\mathrm{http}$ ://reach-energy.eu/wordpress/wp-content/uploads/2014/12/D2.4Local-action-plan-on-energy-poverty Zasavje Focus EN.pdf, 2014. REACH: Local action plan on energy poverty: Pomurje, Slovenia, http://reach-energy.eu/wordpress/wp-content/uploads/2014/12/D2.4Local-action-plan-on-energy-poverty_Pomurje_Focus_EN.pdf, 2014. 
partners prepared an internal transfer workshop for other partners and interested parties, which enabled all partners to equalize the level of knowledge and skills for energy advising and build their capacity to deliver training at national level. The workshop also included implementation of a practical visit to household [30]. Second step was adjusting training modules, products from ACHIEVE project, to the local needs, whereby partners reorganized the training course together with vocational schools and other local actors.

Partners in all 4 countries organized trainings for teachers of vocational and technical schools and volunteers with the aim of capacitating them to perform energy audits. After the training they have been helping partners with training of high-school students and other volunteers, who took over the role of energy advisers in energy poor households. Each partner had to implement 2 trainings for high-school students or volunteers in each pilot area. In Croatia due to specificities of vocational schooling, as key target group, university students have been chosen, following the same approach. Trainings focused mainly on practical issues of implementation of the households visits, regarding energy and water saving devices and tips, data collection sheet, excel program tool for calculation of savings, practical implementation of the visit, communication skills and needs [31]. Less attention was given to technical aspects, as these topics were already covered within the courses of the vocational and technical schools, which were participating in the project.

\section{Identification of energy poor households}

As the term energy poverty is not well known among local stakeholders, and especially not in the target group of the project, we have used a number of relevant indicators [18] for identifying energy poor households: low income, inability to pay energy bills, cold damp living conditions, disconnection from energy supply, self-disconnection (in some countries), debts owed to the energy supplier, health impacts associated with poor living conditions, homes with low energy performance.

First challenge was to identify those households facing problems in affording their basic energy needs. This challenge was tackled by implementing site-tailored discussions and interviews with key actors and local stakeholders that could help with identification of those households most in need. Based on the analysis of local situation and conclusions from discussions with local Centres for social work, various charity organizations and NGOs, such as Caritas and Red Cross, partners decided on their target group of households that were identified to be the most prone to energy poverty. These were households living under the poverty threshold, who either have no or very low income, mostly in the form of social support.

\section{Reaching out to households}

Important element of REACH was developing methodology for accessing the targeted households.
Decision on methodology was based on lessons learned from various projects and tasks implemented in partner countries. In each pilot area campaign for reaching out to households were designed and implemented. While free energy advising should be an appealing service for energy poor households, experience shows that it does take a significant amount of effort to communicate the benefits of participation in the project activities to selected target group. Many households are suspicious, as they have experienced some form of fraud. First step was organizing focus groups, consisting of representatives of energy poor households, experts for social work and partners to debate how to best structure the promotion campaign in the pilot areas. Result of the action were incorporated in local communication plans, which included ideas on how to shape the campaign, how to formulate messages and which channels to use for dissemination.

Based on the local communication plan, key communication tools were developed, such as leaflets and placards. Additional meetings were organized with local actors that have useful channels and contact to energy poor households (e.g. social work centres, municipalities, social workers, charity organizations and NGOs as Caritas and Red Cross etc.).

Experience showed that direct recommendation of the visits by social advisers in social work centres and other charity organizations and NGOs is the best manner to present the visits to households. These actors are most trusted by the target group of energy poor households and are in constant contact with them. Apart from using leaflets and placards, mouth-to-mouth promotion, snowballing and involvement of local media, cooperation with social work centres and charity organizations proved to be the most efficient and successful method for reaching out to households for all partners of the project.

\section{Implementation of the visits in households}

First step of this task was adjusting the data collection sheet and excel tool for calculating energy savings from ACHIEVE to the needs of REACH (adjustments and translations) [32]. After energy poor households applied for free energy advising through social work centres, Caritas, Red Cross, other charity organization or by leaflets which contained application forms, they were contacted by telephone to set the date for the visit, collect first information and prepare them for the visit with additional instructions.

Visits were implemented in pilot areas and were carried out by high-school students or volunteers who were trained for the purpose of energy advising in households. Energy advisers were implementing the visits in pairs, accompanied by a mentor on first few visits. Energy advising in energy poor households was done in two visits. During the first visit in a household, energy audit and analysis was performed. Advisers checked energy and water bills of the household, conducted a set of measurements (electricity consumption of devices, light bulbs, water flow on taps and shower) and discuss household's habits in energy and water use. By doing 
this, advisers identified potentials for energy and water savings in the household. Data was systematically written in the data collection sheet.

All information and data gathered during the first visit was fed into excel tool for analysis. Inserting data on energy and water use and costs (from bills), electricity using devices (lightning, cooking, washing, entertainment, cooling, heating...), state of the building (heating system, insulation, windows, position of flat...) and behaviour of the inhabitants enabled the energy advisers to run analysis for each household, calculate energy and water savings and shape advices for reducing energy and water use. Result is a report, which was given to the households at second visit, and contains all relevant data regarding their energy and water consumption and savings.

During the second visit, the advisers presented the report to the household and installed energy and water saving devices. The package of devices, which is free of charge for energy poor households, was tailored to the needs of the households (e.g. power switch, tap aerators, efficient light bulbs, thermometers, draft proofing for windows and doors, efficient shower heads, reflective panel for radiators). Then tailor-made energy saving advices for the household were presented, taking into consideration the situation and habits of the members. The household was specifically notified about the structural problems in their households, such as poorly insulated building, inefficient heating system or mould. Apart from tailor-made advice, the households received a guidebook that consists a list of general advices for reducing their energy and water use and contacts to institutions that can support them in making further steps (e.g. insulation funds, charity organizations).

In case of need, partners have provided post-visit support for households in the form of helping households apply for available funds, where they are available, assisting households in changing their energy provider, communicating problems of the buildings with the building managers, establishing contact with social structures.

Two ways of addressing the problem: technical solutions and awareness raising

Purpose of the visits is seen in two ways. First one is to help energy poor households with technical solutions in the form of energy and water saving devices. The impact of these devices can be calculated in kWhs of energy or litres of water saved based on their characteristics and compared with situation in home before the devices have been installed. With instalment of these devices household directly benefits from energy and water savings as bills are reduced after installation of the devices. Other purpose is to raise awareness about energy and water consumption and ways of reducing that consumption, and to empower households to reduce their energy and water use through habits and behaviour change. Households are provided with energy and water saving advices and contacts of various actors and institutions that can provide additional information or support them in making further steps. In that way household is encouraged to engage in the topic of energy use, to be better informed about energy related matters, and to gain more knowledge in the field of energy and water savings. All of it can be potentially beneficial for the household as it can result in more energy and water savings and rational use of energy and water.

\section{Monitoring visits and results}

To ensure appropriate evaluation, partners monitored the visits. Main form of monitoring included checking the data collection and reports from visits and constant monitoring of the work of advisers. For this reason constant support for advisers during the visiting process was provided by the partners (e.g. answering questions, checking the excel tools, providing further information, constant communication). Advisers were equipped with a 'to-do' list, which helped them with the process of implementation of the visits.

Evaluation of the impacts and success of the household visits helps in understanding the effectiveness of the activities and achievements that the action brought. For that reason it is considered one of the most important tasks of the project. Evaluation of visits was done based on methodology and tools that were developed under the project ACHIEVE and appropriately adjusted for causes of REACH. Evaluation of the visits consists of two parts. First is evaluation of results of the analysis and savings calculations from the excel tool. Second is evaluation of the success of the visits (e.g. reduction of energy and water use, change of habits, use of installed devices, satisfaction with the service), which is carried out by telephone survey. It covered $1 / 3$ of the visited households, which were called and asked questions regarding the visit of energy adviser and their potential energy efficiency related actions and behaviour changes after the visit. Telephone surveys were conducted at least 6 months after the second visit to allow for the potential new habits to settle in. When compared to the baseline, which was established during the first visit (with energy audit), the evaluation enables quantification of impacts of the visits. The information, obtained through the survey, will be analysed and evaluation report will be prepared at the end of the project.

\subsection{Developing Structural Solutions}

To ensure such a wide dialog and trigger action among many different stakeholders and actors, a set of activities needs to be put in place that endorses energy poverty among decision-makers and attempts to trigger their response and action. The section describes these activities in detail.

\section{Adjusting the plans to the political situation}

Unlike many other activities, policy work cannot be fully planned long time in advance as the best results are achieved when it is adjusted to the circumstances (political situation) of the moment. This is why the first step in policy work is to fine-tune the planned activities to the current political situation. The step demands an analysis of the political 
situation and key actors, answering questions, such as: What is the external strategic context (political, public, business)? Whose help or support is needed in the policy work? Who are the strongest allies? Who is likely to oppose? What aims to communicate to the decision-makers?

\section{Shaping of recommendations for decision-makers}

Taking into consideration the analysis of the energy poverty situation in the different countries, but also the analysis of the political context, it is an important step to compile possible policy recommendations for decision-makers. Recommendations should provide a short context of the energy poverty on national level, suggest definition for energy poverty on national level, list possible measures/solutions on energy poverty at national and local level and introduce several examples of good practices from the country or abroad. In the case of $\mathrm{REACH}$, the recommendations were done according to a joint framework (terms of reference), based on which each partner prepared recommendations for its country. It is useful to include decision-makers in the shaping of recommendations (ask several decision-makers to review the recommendations and suggest improvements) as this can increase the feeling of ownership of the recommendations and lead to a smoother implementation. Based on the cross-cutting topics of the national recommendations, EU level recommendations can be composed, reflecting the situation in the SEE region and casting light on what the specifics for the SEE region are as compared to the general EU policy measures.

\section{National level policy work}

Among the many possible ways for doing advocacy or policy work, within project REACH the following methods and approaches were (or still will be) used:

- Placing energy poverty on decision-makers mind-maps: This activity encompasses sending of policy briefing (recommendations) to key decision-makers at national and local level and appealing to put energy poverty on their policy agenda. The sending of the recommendations is followed up by an invitation to personally engage in further activities.

- Organising high-level debates on energy poverty: This activity is about implementing high-level national debate on energy poverty (with wide media coverage, so as to act as awareness raising at the same time). Along with the key actors in the field, visible decision-makers and experts (national or international) take part in the debate to trigger measures and actions at national level. A slightly different form of such a debate can also be a parliamentary hearing, as a tool to motivate decision-makers.

- Advocacy meetings and working groups: This activity encompasses direct meetings with key decision-makers and - where feasible - participation in governmental working groups. Other examples of activities that can be undertaken are: involving decision-makers in the implementation of the project by engaging them in work with households, suggesting energy poverty as an issue to highlight during election campaigns in countries where national or local elections take place, suggesting use of EU funds for energy poverty actions.

- Organising media attention for the energy poverty issue: This activity involves organising of press conferences around debates, communication with selected media/journalists to place the issue (e.g. through interviews) or creating photo opportunities (e.g. training of energy advisors or executing practical measures).

EU and international level policy work

Because for the EU member states, but also many countries in the EU neighbourhood, energy and social policies are shaped in Brussels, it is relevant to conduct advocacy also at the EU level. This is especially important for representing the South-east European region in the EU or international level policy debates and processes. The work consists of the following outlined activities:

- Placing energy poverty at EU level decision-makers mind maps: This activity is about sending the composed recommendations to relevant EU decision-makers (officials in selected DGs, members of the European Parliament, permanent representatives in Brussels) and appealing to put energy poverty on their agenda and/or highlight aspects of energy poverty, which are specific for South-east European region. The sending of the recommendations is followed up by an invitation to personally engage in further activities.

- Organisation of debate in the European Parliament: A debate on challenges of energy poverty in new member states is organised in the European Parliament to highlight the specifics of the SEE in the energy poverty issue.

- Meetings with EU level decision-makers: Under this activity, meetings with several decision-makers are organised to enable personal and direct presentation of the key issues in the field of energy poverty in South-east European region. The targets for meetings are mostly MEPs.

- Participating in on-going EU debates / events: This activity mainly aims at representing the specifics of the South-east European region in the EU level debates and events on energy poverty.

- Energy poverty in Energy community's agenda: Energy Community (www.energy-community.org) is an international platform, which extends the EU internal energy market to South East Europe and beyond on the ground of legally binding framework to provide a stable investment environment and tie the Contracting Parties together with the European Union. Energy poverty is one of the issues, which Energy Community is working on and hence the recommendations are presented to the Community's secretariat and working bodies. 
Evaluation of policy process

The last, but important aspect is the evaluation of the policy work. This is done through developing a framework for evaluation of the policy process and implementing the evaluation. The evaluation framework is based on previous experience (e.g. from IEE project AID-EE or numerous academic studies), but adjusted to the needs of REACH. It ensures that evaluation gives information on the impact of policy work, achieved results and effectiveness of it. Most of the partners perform the evaluation - based on the framework - by themselves, but it can also be done by an external expert. A short report is prepared about the evaluation. The same process is done for the EU level policy work.

\section{Results}

\subsection{Results of the Practical Approaches}

$\mathrm{REACH}$ is still an on-going project; therefore there are no final results yet. For this reason we are presenting results from project ACHIEVE, which was implemented with the same methodology between April 2011 and April 2014. 1920 Households were visited. On average, ACHIEVE resulted in over 140 EUR and almost $300 \mathrm{~kg} \mathrm{CO}_{2}$ of annual savings per visited household (see Table 4). Presented figures in the table are not to be compared directly between countries as each of the covered countries had its own specifics (different energy and water prices between countries, different $\mathrm{CO}_{2}$ emission factors).

Table 4. Average savings per year and household on national level and on project scale

\begin{tabular}{|c|c|c|c|c|c|c|c|c|}
\hline & & Slovenia & Bulgaria & UK & France & Germany & Project level & $\begin{array}{c}\text { Savings in \% } \\
\text { of the } \\
\text { average } \\
\text { consumption }\end{array}$ \\
\hline \multirow{3}{*}{ electricity } & $\mathrm{kWh}$ & 274 & 335.7 & 193.2 & 435.4 & 312.52 & 331.04 & \multirow{3}{*}{$9,48 \%$} \\
\hline & $€$ & 39.28 & 33.57 & 32.89 & 54.99 & 78.03 & 48.96 & \\
\hline & $\mathrm{kg} \mathrm{CO} 2$ & 152.6 & 229.3 & 86.1 & 87.1 & 196.26 & 139.74 & \\
\hline \multirow{2}{*}{ water } & $\mathrm{m}^{3}$ & 17.5 & 9.4 & 3.5 & 34.2 & 27.53 & 21.07 & \multirow{2}{*}{$18 \%$} \\
\hline & $€$ & 35.98 & 6.97 & 8.12 & 81.91 & 104 & 53.15 & \\
\hline \multirow{3}{*}{ heat energy } & $\mathrm{kWh}$ & 554.9 & 257.7 & 400 & 794.7 & 750.63 & 592.11 & \multirow{3}{*}{$6,29 \%$} \\
\hline & $€$ & 33.61 & 19.71 & 24.46 & 53.23 & 64.88 & 41.52 & \\
\hline & $\mathrm{kg} \mathrm{CO}_{2}$ & 168.1 & 113.5 & 76.7 & 223.45 & 155.75 & 160.16 & \\
\hline \multirow{2}{*}{ total } & $€$ & 108.87 & 60.25 & 65.47 & 190.14 & 246.91 & 143.63 & \multirow{2}{*}{ I } \\
\hline & $\mathrm{kg} \mathrm{CO}_{2}$ & 320.7 & 342.8 & 162.8 & 310.55 & 352.01 & 299.9 & \\
\hline
\end{tabular}

Source: [33] 
Regarding REACH, more than 25 high-school teachers and more than 140 high-school students and volunteers were trained for energy advisers in 6 separated trainings in 4 countries. They have already in the course of the project visited a total of 938 households (situation at the end of August 2015). Evaluation of the visits is still an on-going process, for which reason there are still no results available about achieved savings in households, potential behaviour changes and their satisfaction of the service.

Table 5. Number of visited households in REACH project

\begin{tabular}{|c|c|}
\hline Country & Number of visited households \\
\hline Bulgaria & 330 \\
\hline Croatia & 304 \\
\hline Macedonia & 95 \\
\hline Slovenia & 210 \\
\hline Total & $\mathbf{9 3 9}$ \\
\hline
\end{tabular}

Source: [34]

Apart from that, partners have:

- organized an internal transfer workshop for partners and interested parties, which was which was held in Ljubljana in April 2014 and attended by 37 people,

- adjusted training content and modules from ACHIEVE project to their needs,

- adjusted data collection sheet and excel program tool for calculation of savings that are used by advisers for the implementation of the visits,

- developed a training module that can be used in other technical and vocational schools,

- designed and distributed materials for communicating the service locally,

- developed guidebooks for households, which includes energy and water saving advices, contacts to institutions that can support them in making further steps, and other beneficial information regarding energy and water savings and appropriate use of energy,

- motivated over 40 local actors to follow energy poverty, be involved in assessment of local situation and be connected into local networks to address energy poverty

- secured commitment of over 30 local actors to fight against energy poverty.

\subsection{Policy Recommendations}

In 2010 European Economic and Social committee noted that: The prices of electricity, gas and other fuels such as coal are still rising, and this trend looks set to continue in the coming years, which means that, unless swift and effective action is taken, the number of vulnerable energy consumers could also increase markedly [35]. Five years later, there is still no clear definition of who the vulnerable consumers are, how many families suffer from adverse impacts of energy poverty, and how many are in danger to cross the line and become vulnerable as result of the poor economic situation and increase of energy prices in the country. It is clear that the public authorities will be forced to take specific measures for amortisation of the impact of increased energy prices, however, up to date there are no clear guidelines or systematic approaches on how it will be done.

Energy poverty first entered European policy through the so-called "Third energy package" through EU directives for internal markets for electricity (2009/72/EC) and gas $(2009 / 73 / \mathrm{EC})$. Those directives request member states to define energy poverty and to protect vulnerable consumers of energy the unified approach and clear guidelines on how this should be achieved are still missing. EU Directives for the internal markets for electricity (2009/72/EC) and natural gas $(2009 / 73 / \mathrm{EC})$ recognise that energy poverty is a growing problem in the Community. The Directives introduce a requirement for Member States to, firstly, define the concept of vulnerable customers, specifically indicating that this may refer to energy poverty, and, secondly, to take appropriate measures through national action plans or frameworks, social security systems or support for energy efficiency improvements to address energy poverty where identified. Directive on internal market in electricity (2009/72/EC) states: Energy regulators should also be granted the power to contribute to ensuring high standards of universal and public service in compliance with market opening, to the protection of vulnerable customers, and to the full effectiveness of consumer protection measures.

Energy Efficiency directive (2012/27EU), hereinafter EE directive, states that the common framework should allow Member States to include requirements in their national scheme that pursue a social aim, in particular in order to ensure that vulnerable customers have access to the benefits of higher energy efficiency. Furthermore, EE directive notes that within the energy efficiency obligation scheme, Member States may include requirements with a social aim in the saving obligations they impose, including by requiring a share of energy efficiency measures to be implemented as a priority in households affected by energy poverty or in social housing. The EE directive is trying to secure energy efficiency of dwellings and appliances. Although it does not directly tackle energy poverty, it demands improvements in energy performance, which can help reduce energy use and hence address energy poverty. The EE directive stimulates use of EU funds, establishment of financing facilities and prioritizing energy poverty in energy efficiency obligation schemes, but, again, eradication of energy poverty is not set into a central position.

None of the directives provides definition of energy poverty or vulnerable customer.

EU has been putting high effort into liberalizing the energy market, yet this is one of the factors that contributed to energy poverty: removing market barriers is estimated to have contributed to increasing the likelihood for facing energy poverty [36]. Prices have been continuously rising 
throughout years (see Figure 1), and it is likely that this trend will continue.

Energy prices are further increased by different taxes and levies, which further increase the burden on final consumers. Some governments opt for their policy solutions for energy poverty to be focused on energy prices. Prior to making such decision it is important to consider that the price consumers pay for electricity and gas reflects various elements, influenced by both market forces and government policy. European commission states that it is of crucial importance to understand energy pricing mechanisms and structure when defining possible financial and legislative frameworks for tackling energy poverty to prevent passing costs to consumers [38].

Energy pricing is a complex issue, and while energy prices are considered to primarily be market driven in the fully liberalised markets, it is important to note ever-growing impact of taxes and levies (see Figure 2), that raise final prices of energy and energy products for end costumers.

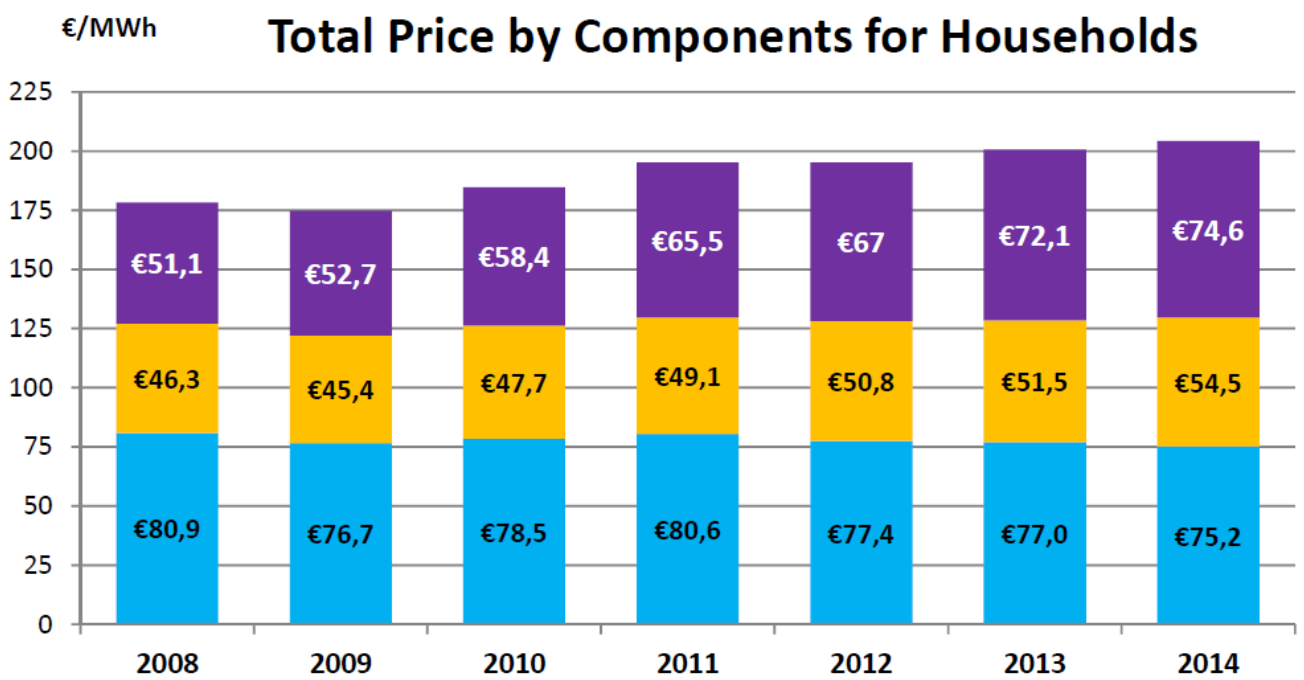

Taxes \& PSCs Network Energy \& Supply

Source: [37]

Figure 1. Electricity Price by Components for Households

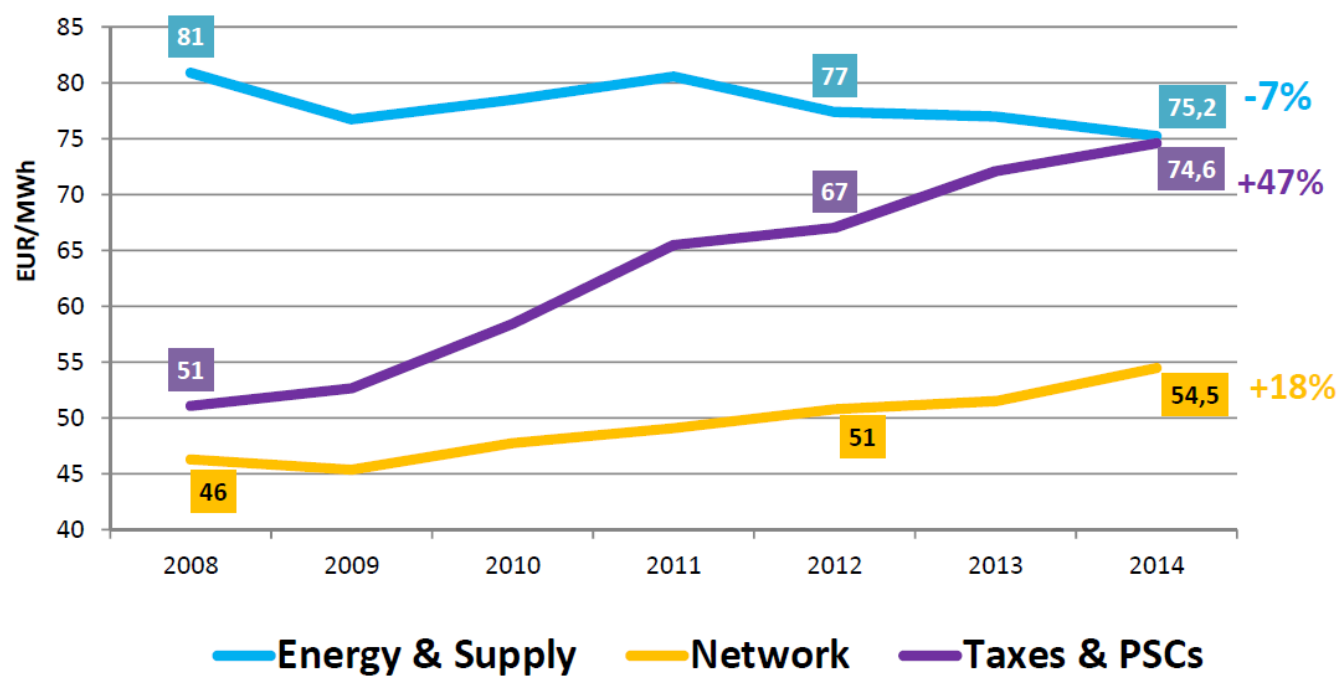

Source: [37]

Figure 2. Evolution of Household Price Components 
This is why it is indispensable to seek corrections to the adverse impacts of energy market liberalization and to avoid policy solutions through different taxes and levies on the already burdened household bills.

Investing in whole range of energy efficiency solutions from simple low - cost EE measures as it is done in ACHIEVE and REACH through full retrofitting of buildings, has proven to be the best mechanism for alleviating all aspects of energy poverty. EE measures help reduce energy consumption and thus decreases energy bills and it also deals directly with one of key causes of energy poverty - low energy efficiency of building and appliances. Energy efficiency helps improve quality of life through decreased air humidity and thus mould and draft, resulting in improved health conditions.

Benefits of energy efficiency have long been recognised and many countries have established a variety of mechanisms to promote energy efficiency [6], from subsidies for renovation to energy advising networks for citizens. The issue with current policies is that they are not designed to target energy poor households and hence they often fail to provide support for energy poor households; for example, energy advising is often designed to provide advice for people who can make investments, which is not useful for energy poor households as they usually cannot accumulate funds for investments [39].

Energy poor households typically fail to use available mechanisms because the application documentation is too demanding. In short, general awareness raising, information or financial assistance programs do not meet the needs of the energy poor households. Hence, it is necessary to adjust those mechanisms by adjusting the communication, advising, support and information for the energy poor households.

Another important feature of tackling energy poverty is that normally energy efficiency actions are in the domain of energy authorities, while energy poverty is specifically a social phenomenon. The social structures (social workers, social centres), however, perceive measures for tackling energy poverty as a technical issue. In addition, social structures are usually understaffed and lack knowledge about how to deal with energy poverty. As a result, there is serious lack of communication among the set of actors who should be cooperating closely to address energy poverty. To this end, it is important that networking and connections between the key actors are stimulated on an on-going basis.

It is of crucial importance that energy and social policies are aligned in the segment of energy poverty and that social protection funds are also directed towards energy poverty. Provision of simple energy efficiency measures can provide relief in energy costs and improve quality of indoor conditions for many families in SEE. Through project $\mathrm{REACH}$, this approach has proven effective as a first step towards the solution. Many of the visited households live in such harsh conditions that it is doubtful that even if they would be granted possibility for full energy efficiency retrofitting of the building it would be possible due to deteriorated state of the building. Many buildings are of sub-standard construction quality and it would not be cost-effective to undergo refurbishment.

SEE countries face specific issues and generally are worse off than western countries when it comes to energy poverty. It is thus necessary to take those conditions into consideration when designing policies for tackling energy poverty. Energy efficiency should be taken as first step through provision of low-cost solutions to all vulnerable households, and criteria should be developed based on which some households would be eligible for larger investments. Only after energy efficiency measures, if the households still face problems achieving sufficient quality of energy services, they should be given financial support as they are now in many SEE countries.

\section{Discussion}

In the practical aspect of abating energy poverty, changing behaviour plays a crucial role. Yet, changing of individual's behaviour to mitigate environmental problems is much harder than simply implementing a new technology. Behaviour change is "a must" for solving problems that do not have technical solutions. Dunlap [38] recognises three types of social corrections: (1) cognitive corrections (corrections of knowledge), which assume that education and awareness raising will suffice for achieving the desired changes in behaviour; (2) structural corrections, which are related to the laws and regulations that can influence changes; and (3) indirect behavioural corrections, which include stimulations and obstacles for triggering change in behaviour. Gärling et al. [43] claim that when changing individuals behaviour, first new purpose (e.g. environmental purpose) needs to be developed, which is hard in case an old habit needs to be changed. This means that the new purpose will be in conflict with the old habit. The second problem is that a new value must be present to affect the choice.

Although the behavioural model of a rational economic man has dominated economic theory and policy for 100 years or more, people are much less rational in practise [44-47]. Irrational behaviour is more of a rule than rational behaviour. Because of this, there are several psychological 'oddities' that make it complicated to change behaviour in order to address the energy poverty. People's decisions are often run by the reptilian part of brain, but they justify them logically [48]. The reptilian brain, where instincts - mainly survival and reproduction - are based, prevails over the two parts that developed later. In a battle between logic, emotion and instinct, the instinct wins. Because of this, people are less likely to change their beliefs and opinions. According to Hagens and Bertman [49-50], human neural mechanisms give a strong preference to the present over the past or future. Ariely [44] explains that for people it is hard to give up consumption today for the good of the distant future; it is more acceptable to give up consumption in the future or give up something they do not have yet.

All the listed oddities have to be kept in mind when 
designing the answers to the energy poverty challenge, especially in the field of behaviour changing measures.

Project REACH seems to have a good resonance with the different stakeholders. For example, in Slovenia, the project was selected as one of the winning projects for disseminating good practices in the field of energy efficiency [51]. Apart from that, the Slovenian government adopted the concept of visiting energy poor households and is now running a nation-wide program to support those households [52]. The development of the national level program was triggered by an official from the Ministry of Infrastructure - Directorate for Energy. During the kick-off event of REACH, the government official was informed about the practices in other countries and soon the Ministry of Infrastructure and Ministry of Environment started to develop the national program for Slovenia. The visits are implemented by the national network of energy advisers, EN-SVET, because this is the structure, which was already in place and useful for the purpose. In Croatia key authorities gave support to project $\mathrm{REACH}$, and as direct result other similar projects have been developed and are now implemented, and energy poverty is steadily rising on Croatian policy agenda.

As of November 2015, REACH is also implemented in three more countries, Serbia, Bosnia and Herzegovina and Montenegro [53]. The methodologies are slightly simplified (one visit instead of two, no phone based evaluation of the visits), but for the rest the REACH methodology is used to implement the activities in the three additional countries. The activities in the additional countries are mostly pilot activities (only 100 visits per country), but they illustrate how to address the complex problem and bring the different stakeholders together to continue working on the issue.

\section{Conclusions}

While project REACH is still in implementation stage (to be finalised in February 2017) and it is not possible to assess all of its impacts, its contributions are already measurable and significant. Immediate relief has been provided to involved households, and progress has been made in policy context both in the region and on EU level.

First lessons learned and analyses of mistakes that can be avoided in the future are already available from the interim report [34]:

- Some households are reluctant for a participation in the project. In Macedonia people are reluctant to accept the visit, although they received the information from Red Cross, Retired People Organization and Organization of handicapped people. This is because the people are insecure and vulnerable and think that everything is politically motivated. Cooperation with the organizations that have access to households is a must and has to be well planned and also different dissemination methods have to be employed. In Croatia it was necessary to start the fieldwork in joined coordination with local NGOs whom households already trust.

- It is imperative to integrate activity of field visits into some official program. In Croatia it was originally planned to become part of curriculum in vocational schools, but due to changes in national legislation, this was not possible. Basing the work on volunteering schemes complicates and prolongs implementation period and increases efforts from project team as each new person needs to be additionally educated on how to implement field visits, collect and report data, and how to interact with vulnerable groups. Inclusion of energy advisor trainings in vocational programmes, university programmes or specific educations, for i.e. unemployed, offers great opportunities.

- to enable success of envisaged activities detailed desktop studying of the legislation in all possible aspects if of utmost importance: security and safety during the visits was noted as one of possible issues; the fact that the students of vocational schools are minors can also be problematic in some cases; there is an issue of taxation of gifts and donations. To avoid any barriers and undesired effects good preparation is the key. It is very important to talk to the variety of actors that are involved in the implementation and listen to them, as they are the ones that can highlight such regulatory problems.

- It was found that students taking part in the field visits are very satisfied with the action and their taking part in it. They give feedback that they find it interesting and that they learn a lot of practical aspects.

Further lessons and conclusions can be drawn from the experiences of project ACHIEVE [33, 40-41]:

- it was discovered that during training it is necessary to emphasize knowledge about social issues, so that the advisers are able to identify social problems (involve social workers in the training sessions so that advisers know how to identify social issues too, not only technical);

- it is important to train about communication requirements;

- it is necessary to clearly define the limits of the mission during the training to limit frustrations for advisors and households (in practice it often happens that the household expects more than advisor is able to give, as well as that advisors attempt to provide support for which they are not qualified to provide);

- it is important to better inform the advisers about possible solutions they can propose to households at the end of the visit (orientate them towards the proper structures);

- when recruiting energy advisers to be trained, a particular focus should be put on their social and communication skills: even if a large part of the work around the visits is technical (assessment and calculation of the main possible energy and water savings, advice given to households to reduce their 
consumptions...), the visits are also largely about "human" contact;

- it is suggested that visits are performed by two advisors, one of whom has an emphasis on technical skills, and the other has an emphasis on social skills;

- to avoid disappointments when starting energy advising in practice it is suggested that the potential advisors do one visit before they get fully involved in the project;

- time dedicated to training should not be underestimated and neither should be the time dedicated to supervise/follow the advisers before they can be fully operational on their own;

- the time needed for one visit can be much higher than expected, as people might have a lot to say to advisers (not necessarily strictly linked to the core purpose of the visit)

- a lot of critical situations linked to unsanitary / inadequate housing or extreme poverty situations call for the need to organize appropriate responses and procedures when such situations are needed (systematically linking with different services);

- creating and maintaining local networks is time consuming and it must be done regularly;

- there can be barriers when working with social/health services.

\section{REFERENCES}

[1] European Fuel Poverty and Energy Efficiency Project (EPEE). Tackling Fuel Poverty in Europe: Recommendations Guide for Policy Makers. Ademe, 2009. Online available from: http://www.fuel-poverty.org/files/WP5 D15 EN.pdf

[2] B. Boardman. Fixing fuel poverty. Challenges and Solutions. Earthscan, London, 2009.

[3] S. Tirado Herrero and D. Ürge-Vorsatz. Trapped in the heat: A post-communist type of fuel poverty. Energy Policy, vol. 49, pp. $60-68,2012$.

[4] EU Fuel Poverty Network. Households unable to afford to keep their home adequately warm. Online available from: http://fuelpoverty.eu/wp-content/uploads/2011/12/eu-fp-map -final-v2.jpg

[5] H. Thompson. Is the EU doing enough? EU Fuel Poverty Network, 2012. Online available form: http://fuelpoverty.eu/ 2012/02/10/is-the-eu-doing-enough/\#more-400

[6] European Fuel Poverty and Energy Efficiency Project (EPEE) European Fuel Poverty and Energy Efficiency. Ademe, 2009. Online available from:https://ec.europa.eu/energy/intelligent /projects/sites/iee-projects/files/projects/documents/epee_eur opean_fuel_poverty_and_energy_efficiency_en.pdf

[7] B. Boardman. Fuel poverty: from cold homes to affordable warmth. Belhaven Press, 1991.

[8] J. Hills. Getting the measure of fuel poverty: Final Report of the Fuel Poverty Review. CASE, 2012.
[9] DECC. Annual Report on Fuel Poverty Statistics 2013. Online available from: https://www.gov.uk/government/uploads/sys tem/uploads/attachment_data/file/199833/Fuel_Poverty_Rep ort_2013_FINALv2.pdf

[10] R. Schuessler. Energy Poverty Indicators: Conceptual Issues Part I: The Ten-Percent-Rule and Double Median/Mean Indicators. ZEW - Centre for European Economic Research Discussion Paper No. 14-037, 2014.

[11] S. Buzar. Energy Poverty in Eastern Europe: Hidden Geographies of Deprivation. Ashgate Publishing, Ltd., 2007.

[12] B. Boardman. Opportunities and Constraints Posed by Fuel Poverty on Policies to Reduce the Greenhouse Effect in Britain. Applied Energy 44, pp 185-195, 1993.

[13] J. D. Healy, J. P. Clinch. Fuel poverty, thermal comfort and occupancy: results of a national household-survey in Ireland. Applied Energy 73, pp 329-343, 2002.

[14] C. Liddell, C. Morris. Fuel poverty and human health: A review of recent evidence. Energy Policy 38, pp 2987-2997, 2010.

[15] C. Waddams Price, K. Brazier, W. Wang. Objective and subjective measures of fuel poverty. Energy Policy 49, pp $33-39,2012$.

[16] R. Moore. Definitions of fuel poverty: Implications for policy. Energy Policy 49, pp 19-26, 2012.

[17] H. Thompson, C. Snell. Quantifying the prevalence of fuel poverty across the European Union, Energy Policy 52, pp 563-572, 2013

[18] ACHIEVE. Achieve Newsletter No. 1. Online available from: http://www.achieve-project.eu/index.php?option=com_phoc adownload\&view $=$ category\&download $=15 \% 3$ Aachieve-new sletter-issue- $1 \& \mathrm{id}=32 \% 3 \mathrm{Aeu}$-dissemination $\&$ Itemid $=6 \&$ lan $\mathrm{g}=\mathrm{eeu}, 2011$

[19] A. Stojilovska, S. Zuber. EU Policy Briefs: Macedonia. , Analytica Think-Tank, 2013. Online available from: http:/www.kas.de/wf/doc/kas_35851-1522-2-30.pdf?131024 122211

[20] UNDP, GfK Centar za istraživanje tržišta. Energy poverty survey in Croatia. UNDP, GfK, 2013.

[21] CENEP. Anketa o energetskoj učinkovotosti u kućanstvima. Online available from:http://cenep.net/uploads/cenep/docum ent_translations/doc/000/000/069/anketa_-_RH.pdf?2013

[22] ACHIEVE. Achieve project presentation leaflet. Online available from:http://www.achieve-project.eu/index.php?opt ion $=$ com_phocadownload\&view $=$ category \&download $=12 \%$ 3 Apresentation-leaflet-achieveeu\&id=32\%3 Aeu-disseminati on\&Itemid=6\&lang=eeu, 2011

[23] P. Howden-Chapman, H. Viggers, R. Chapman, K. O'Sullivan, L. T. Barnard, B. Lloyd. Tackling cold housing and fuel poverty in New Zeland: A review of policies, research, and health impacts. Energy Policy 49, pp 134-142, 2012.

[24] J. D. Healy and J. P. Clinch. Quantifying the severity of fuel poverty, its relationship with poor housing and reasons for non-investment in energy-saving measures in Ireland. Energy Policy, vol. 32, no. 2, pp. 207-220, Jan. 2004.

[25] REACH. Project REACH documentation. 
[26] REACH. Report on national situation in the field of fuel poverty: Bulgaria. Online available from: http://reach-energy .eu/wordpress/wp-content/uploads/2014/12/D2.2-EAP_EN.p df, 2014.

[27] REACH. Mapping the national situation on energ poverty: Croatia. Online available from: http://reach-energy.eu/wordp ress/wp-content/uploads/2015/01/D2.2-DOOR_EN.pdf, 2015.

[28] REACH. Mapping the national situation on energy poverty: Macedonia. Online available from: http://reach-energy.eu/w ordpress/wp-content/uploads/2014/11/D2.2-Macef_EN.pdf, 2014.

[29] REACH. Report on national situation in the field of energy poverty: Slovenia. Online available from: http://reach-energy .eu/wordpress/wp-content/uploads/2014/12/D2.2-Focus_EN. pdf, 2014.

[30] REACH. Proceedings of training for partners. Online available from: http://reach-energy.eu/wordpress/wp-content/uploads/ 2015/01/D3.2-Proceedings-of-training-for-partners.pdf, 2015.

[31] REACH. Training course for energy advisers and proceedings of training for energy advisers. Online available from: http://reach-energy.eu/publications, 2015.

[32] REACH. Data collection sheet and excel tool for calculation of savings. Online available from: http://reach-energy.eu/public ations, 2015.

[33] ACHIEVE. Final publishable report. Online available from: http://www.achieve-project.eu/index.php?option=com_phoc adownload \&view $=$ category \&download $=332 \% 3$ Afinal-publi shable-report-achieve $\& \mathrm{id}=32 \% 3 \mathrm{Aeu}$-dissemination $\&$ Itemid $=6 \&$ lang=eeu, 2014 .

[34] REACH. Interim report.

[35] European Commission. TEN/420 Energy poverty - the impact of liberalisation and the economic crisis OPINION of the European Economic and Social Committee on Energy poverty in the context of liberalisation and the economic crisis (Exploratory opinion). EC, Brussels, 2010.

[36] Poggi, A., Florio, M. Energy deprivation dynamics and regulatory reforms in Europe. Energy Policy, 38 (1), 253-264, 2010.

[37] Eurelectric. Drivers of Electricity Bills: Supporting graphs, methodology and country notes. A EURELECTRIC methodology note. Eurelectric, 2016.

[38] European Commission. Energy prices and costs in Europe, $\operatorname{COM}(2014) 21$ final du 22.1.2014. Online available from: http://ec.europa.eu/energy/doc/2030/20140122_communicati on_energy_prices.pdf
[39] Information from ENSVET- energy advising network in Slovenia.

[40] ACHIEVE: Achieve Project Meeting 4 Minutes, 2013.

[41] ACHIEVE: Achieve draft interim report, 2013.

[42] R. E. Dunlap. Environmental Sociology. In Handbook of Environmental Pyschology, ed. R. B. Bechtel and A.Churchman, 176-187. John Wiley \& Sons, New York, 2002.

[43] T. Gärling, A. Biel and M. Gustafsson. The New Environmental Pyschology: The Human Interdependence Paradigm. In Handbook of Environmental Pyschology, ed. R. B. Bechtel and A.Churchman, 176-187. John Wiley \& Sons, New York, 2002.

[44] D. Ariely. Predictably Irrational. HarperCollins Publishers, New York, 2009.

[45] J. M. Gowdy. Behavioural Economics and Climate Change Policy. Journal of Economic Behaviour \& Organization, 68: 632-644, 2008.

[46] K. Gram-Hanssen. Standby Consumption in Households Analyzed with a Practice Theory Approach. Journal of Industrial Ecology, 14, 1: 150 - 166, 2010.

[47] S. Mullainathan. Solving Social Problems With a Nudge. Online available from:

http://www.ted.com/talks/sendhil_mullainathan.html

[48] C. Rapaille. The Culture Code. Broadway books, New York, 2006.

[49] N. Hagens. The Common Link with Climate Change, Peak Oil, Limits to Growth, etc. - Belief Systems. 2009. Online available from: http://www.theoildrum.com/node/6031 (6 December 2010)

[50] S. Bertman. Hyperculture. The Human Cost of Speed. Praeger, Westport (Connecticut, US), 1998.

[51] REACH. REACH wins award for best promotional project on EE/RES in Slovenia. Online available from: http://reach-energy.eu/blog/2015/04/reach-wins-award-for-b est-promotional-project-on-eeres-in-slovenia-333

[52] REACH. Bringing REACH visits to national level! Online available from: http://reach-energy.eu/blog/2015/01/bringing -reach-visits-to-national-level-319

[53] REACH. Trainings for REACH CEI project partners in Tuzla, Podgorica and Belgrade. Online available from: http://reach-energy.eu/blog/2016/02/trainings-for-reach-cei-p roject-partners-in-tuzla-podgorica-and-belgrade-468 